DOI: https://doi.org/10.24843/JFU.2019.v08.i01.p07

pISSN: 2301-7716; eISSN: 2622-4607

Jurnal Farmasi Udayana, Vol 8, No 1, Tahun 2019, 44-49

\title{
Molecular Docking Terpinen-4-ol pada Protein IKK sebagai Antiinflamasi pada Aterosklerosis secara In Silico
}

\author{
Susanti, N.M.P. ${ }^{1 *}$, N.P.L. Laksmiani ${ }^{1}$, P.P.P. Dewi ${ }^{1}$, P.Y.C. Dewi ${ }^{1}$ \\ ${ }^{1}$ Program Studi Farmasi Fakultas Matematika dan Ilmu Pengetabuan Alam Universitas Udayana, Bukit \\ Jimbaran, Badung, 80361 \\ *Penulis korespondensi:dekpitsusanti@unud.ac.id
}

\begin{abstract}
ABSTRAK
Aterosklerosis merupakan penyakit inflamasi kronis yang diawali dengan disfungsi endotel sehingga terjadi penumpukan lemak dan pertumbuhan plak pada dinding dalam arteri. Disfungsi endotel akan mengaktifkan jalur Nuclear Factor Kappa B (NF-KB) yang melibatkan protein IKK. Terpinen-4-ol merupakan senyawa yang terdapat di dalam rimpang bangle (Zingiber cassumunar) dan diketahui memiliki aktivitas antiinflamasi. Tujuan dari penelitian ini adalah untuk mengetahui afinitas dan mekanisme terpinen-4-ol terhadap IKK sebagai antiinflamasi pada aterosklerosis yang dilakukan menggunakan metode molecular docking. Hasil docking dinilai dari energi ikatan dan ikatan hidrogen yang terbentuk antara terpinen-4-ol dengan protein. Hasil penelitian menunjukkan bahwa terpinen-4-ol memiliki aktivitas dalam menghambat proses inflamasi karena mampu menghambat protein IKK dengan nilai energi ikatan sebesar $-4,89 \mathrm{kkal} / \mathrm{mol}$. Mekanisme molekuler dalam menghambat aktivitas protein IKK melalui pembentukan ikatan hidrogen pada protein-protein tersebut. Hasil tersebut memperlihatkan bahwa terpinen-4-ol berpotensi menghambat proses inflamasi sehingga pembentukan plak aterokslerosis dapat terhambat.
\end{abstract}

Kata kunci: Aterosklerosis, Terpinen-4-ol, Molecular Docking, In Silico

\section{ABSTRACT}

Atherosclerosis is a chronic inflammatory disease that begins with endothelial dysfunction, it caused fat accumulation and plaque growth in the inner arteries walls. Endothelial dysfunction will activate the Nuclear Factor Kappa B (NF-kB) pathway involving IKK proteins. Terpinent-ol is constituent found in the bangle (Zingiber cassumunar) rbizome. The purpose of this study were to determine the affinity and mechanisms of terpinen-4-ol against IKK protein as antiinflammatory in atherosclerosis performed using molecular docking method. The docking result are assessed from the binding energy and hydrogen bonds formed between terpinen - -0 and protein. The result showed that terpinen-4-ol has activity in inbibiting the inflammatory process because it is able to disturb IKK protein with bond energy values $-4.89 \mathrm{kcal} / \mathrm{mol}$. The molecular mechanism in inbibiting the activity of IKK protein through the formation of bydrogen bonds in these proteins. These result show that terpinen 4 -ol has the potential to inhibiting inflammatory process and it caused the formation of atherosclerotic plaque can be obstructed.

Keywords: Atherosclerosis, Terpinen-4-ol, Molecular Docking, In Silico

\section{PENDAHULUAN}

Penyakit kardiovaskuler merupakan penyakit yang diakibatkan oleh adanya gangguan pada jantung dan pembuluh darah. Diperkirakan 17,5 juta orang meninggal karena penyakit kardiovaskular pada tahun 2012 dan 
sebanyak 17,9 juta orang meninggal pada tahun 2016 (WHO, 2017; Kemenkes RI, 2017). Penyakit jantung coroner merupakan penyakit kardiovaskular yang terjadi akibat penyempitan dan penyumbatan pembuluh arteri koroner pada organ jantung sehingga menyebabkan terganggunya aliran darah ke jantung. Penyempitan arteri koroner dimulai dengan terjadinya aterosklerosis (Montalescot et al., 2013).

Aterosklerosis merupakan suatu penyakit akibat proses inflamasi kronis (Warboys, 2011). Disfungsi endotel merupakan awal terjadinya aterosklerosis (Hadi et al., 2005). Disfungsi endotel akan memicu LDL masuk dan terakumulasi pada matriks ekstraselular intima endotel (Douglas el al., 2010). Sitokin akan memicu diferensiasi monosit menjadi makrofag dan memfagositosis LDL-Oksidasi sehingga membentuk sel busa yang berkontribusi dalam terjadinya plak aterosklerosis (Francis and Pierce, 2011; Warboys, 2011). Sitokin yang memicu proinflamasi yang berperan dalam pathogenesis aterosklerosis terdiri dari TNF, IL-1, IL-18. Aktivasi jalur NF-kB diawali dengan aktivasi IKK oleh sitokin proinflamasi dan menyebabkan terjadinya fosforilasi $\mathrm{I}_{K} \mathrm{~B}$. NF-кB terlepas dari kompleks NF-кB-IкB menuju nukleus dan berikatan dengan gen ${ }_{k} B$ sehingga mendukung proses transkripsi gen proinflamasi (Tedgui and Mallat, 2006).

Terpinen-4-ol merupakan salah satu golongan terpenoid yang merupakan konstituen utama yang terkandung di dalam rimpang bangle (Zingiber cassumunar). Penelitian menunjukkan bahwa ekstrak etanol Zingiber cassumunar dapat menghambat COX dan produksi matriks metalloproteinase MMP-2 dengan memblokir jalur sinyal proinflamasi yang melibatkan ERK 1/2, JNK dan p38 pada jalur MAPK (Koontongkaew et al., 2013). Berdasarkan uraian tersebut maka dilakukan penelitian molecular docking secara in silico untuk memprediksi interaksi antara suatu protein IKK dengan terpinen-4-ol secara molekuler.

\section{BAHAN DAN METODE}

\section{Bahan Penelitian}

Bahan yang digunakan dalam penelitian ini adalah protein IKK (pdb id: 2I40) yang didownload

dari https://www.rcsb.org/pdb/home/home.do dan struktur tiga dimensi terpinen-4-ol dibuat dan dioptimasi menggunakan program HyperChem 8.

\section{Alat Penelitian}

Peralatan yang digunakan dalam penelitian ini adalah seperangkat komputer dengan spesifikasi Windows 764 bit dan program Autodock 4.2 pada OS Windows untuk molecular docking, Chimera 1.10.1 untuk preparasi protein, dan HyperChem 8 untuk preparasi dan optimasi struktur tiga dimensi terpinen-4-ol.

\section{Preparasi Protein}

Preparasi protein diawali dengan memilih protein dalam bentuk aktif yang berikatan dengan native ligand. Selanjutnya dilakukan pemisahan native ligand dari protein menggunakan program Chimera 1.10.1 sehingga tersedia pocket cavity dan diketahui bentuk pocket serta koordinat pocket sebagai bahan docking.

\section{Preparasi dan Optimasi Senyawa Terpinen-4-ol}

Struktur 3D terpinen-4-ol dibuat dan dioptimasi dengan program HyperChem 8. Optimasi struktur 3D terpinen-4-ol dilakukan menggunakan metode komputasi semi-empiris AM1 dengan melakukan kalkulasi dengan single point serta optimasi geometri.

\section{Validasi Metode Molecular Docking}

Validasi metode dilakukan dengan redocking native ligand pada protein target yang sebelumnya sudah dipisahkan native ligand-nya menggunakan program Autodock 4.2. Hasil docking akan menunjukkan senyawa dengan energi ikatan terendah untuk berikatan dengan potein target. Kemudian dilihat nilai RMSD senyawa hasil docking. Metode dikatakan valid apabila nilai RMSD yang diperoleh $\leq 3 \AA$ sehingga dapat dilakukan docking senyawa uji dengan protein target (Jain and Nicholls, 2008). 
DOI: https://doi.org/10.24843/JFU.2019.v08.i01.p07

pISSN: 2301-7716; eISSN: 2622-4607

Jurnal Farmasi Udayana, Vol 8, No 1, Tahun 2019, 44-49

Untuk memperoleh metode yang valid, maka dilakukan pengaturan pada grid box sehingga diperoleh nilai RMSD $\leq 3 \AA$.

\section{Docking Terpinen-4-ol pada Protein IKK}

Terpinen-4-ol ditambatkan pada protein yang telah dipisahkan native ligand-nya dengan program Autodock 4.2 menggunakan grid box yang sama dengan saat validasi metode. Hasil yang diperoleh akan menunjukkan senyawa dengan konformasi dan energi ikatan terendah untuk membentuk ikatan dengan protein IKK.

\section{Analisis Data}

Analisis data dilakukan berdasarkan energi ikatan yang diperoleh dari hasil docking. Energi ikatan berhubungan dengan kekuatan ikatan (afinitas) antara senyawa uji dengan reseptor. Mekanisme aktivitas dapat dilihat dari jenis ikatan yang terbentuk antara terpinen-4ol dengan protein IKK.

\section{HASIL}

\section{Preparasi Protein IKK}

Protein IKK memiliki 4 rantai, yaitu rantai A, B, C, dan D. Rantai A dan C mengikat native ligand inhibitor IKK, yaitu 5[5,6-bis(methyloxy)-1H-benzimidazol-1-yl]-3$\{[1$-(2-chlorophenyl)ethyl]oxy $\}-2-$

thiophenecarboxamide (BLZ). Pada penelitian ini preparasi terhadap protein IKK dilakukan menggunakan rantai A. Struktur protein dan native ligand ditunjukkan pada Gambar 1.

\section{Validasi Metode Molecular Docking}

Hasil validasi metode ditampilkan pada Tabel 1 dan visualisasi interaksi yang terjadi ditamplikan pada Gambar 2.

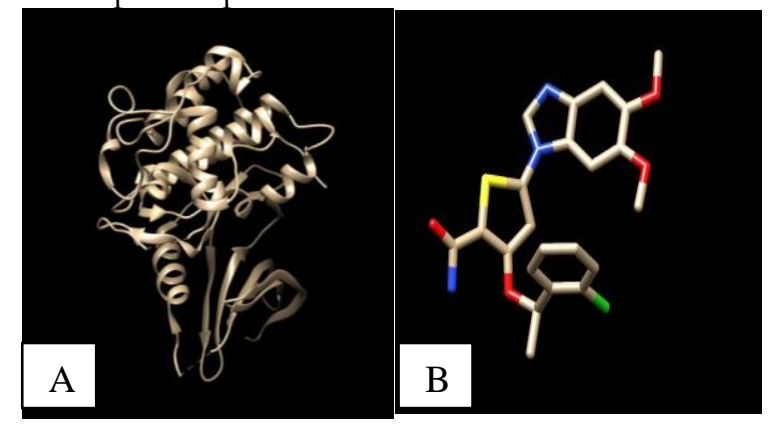

Gambar 1. Struktur Protein IKK (A) dan Native Ligand (B) yang Telah Terpisah
Tabel 1. Hasil Validasi Metode Molecular Docking

\begin{tabular}{|c|c|c|c|c|}
\hline \multirow{4}{*}{ Ligan } & $\begin{array}{c}\text { Energi } \\
\text { Ikatan } \\
(\mathrm{kkal} / \\
\mathrm{mol})\end{array}$ & $\begin{array}{c}\text { RMSD } \\
(\AA)\end{array}$ & $\begin{array}{c}\text { Residu } \\
\text { Asam } \\
\text { Amino }\end{array}$ & Gugus \\
\hline BLZ & $-9,41$ & 0,72 & Leu83 & $\begin{array}{c}\text { HN- } \\
\text { N6 }\end{array}$ \\
\cline { 3 - 5 } & & & Asp145 & $\begin{array}{c}\mathrm{HN}- \\
\text { O25 }\end{array}$ \\
\hline
\end{tabular}

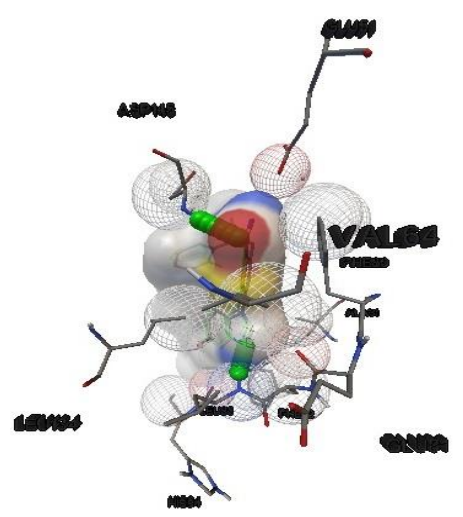

Gambar 2. Visualisasi Interaksi Native Ligand dengan Protein IKK. Ikatan Hidrogen ditandai dengan deretan bola bewarna hijau. Kompleks protein digambarkan berupa struktur di sekitar native ligand

\section{Preparasi dan Optimasi Struktur 3D Terpinen-4-ol}

Struktur 3D terpinen-4-ol dipreparasi dan dioptimasi menggunakan program Hyperchem 8. Hasil optimasi ditampilkan pada Gambar 3.

\section{Docking Terpinen-4-ol}

Docking terpinen-4-ol dilakukan dengan program Autodock 4.2. menggunakan koordinat tempat interaksi seperti native ligand. Hasil docking yaitu berupa energi ikatan dan ikatan hidrogen. Hasil docking ditampilkan 
DOI: https://doi.org/10.24843/JFU.2019.v08.i01.p07

pISSN: 2301-7716; eISSN: 2622-4607

Jurnal Farmasi Udayana, Vol 8, No 1, Tahun 2019, 44-49

pada Tabel 2 dan Visualisasi interaksi yang terjadi ditunjukan pada Gambar 4.

\section{PEMBAHASAN}

Proses preparasi protein dilakukan untuk menyediakan ruang (pocket) sebagai tempat ikatan dengan cara memisahkan protein dengan native ligand-nya. Pada penelitian ini preparasi terhadap protein IKK dilakukan menggunakan rantai A. Hasil dari proses preparasi protein yaitu protein tanpa native ligand dan native ligand yang disimpan dalam bentuk file pdb.

Validasi metode dilakukan dengan redocking protein tanpa ligand dengan native ligand yang telah dipisahkan sebelumnya menggunakan program Autodock 4.2. Parameter dari validasi metode yaitu RMSD (Root Mean Square Deviation). RMSD menunjukkan tingkat penyimpangan hasil docking ligand secara eksperimental terhadap ligand hasil kristalografi pada binding site yang sama. Semakin besar nilai RMSD, maka semakin besar penyimpangan yang menunjukkan semakin besar kesalahan prediksi interaksi ligan dengan protein (Nauli, 2014). Suatu metode molecular docking dikatakan valid apabila memiliki nilai RMSD $\leq 3 \AA$ Jain and Nichollas., 2008). Semakin kecil nilai RMSD yang diperoleh menunjukkan konformasi yang semakin baik karena posisi ligan hasil redocking yang semakin mendekati posisi ligand hasil kristalografi (Bissantz et al., 2000). Berdasarkan hasil yang diperoleh dapat dikatakan bahwa metode sudah valid. Selain menghasilkan data berupa nilai RMSD, dalam tahap validasi juga diperoleh data berupa energi ikatan dan ikatan hidrogen yang terbentuk antara native ligand dengan residu asam amino pada protein. Energi ikatan menunjukkan afinitas dan kestabilan ikatan antara native ligand

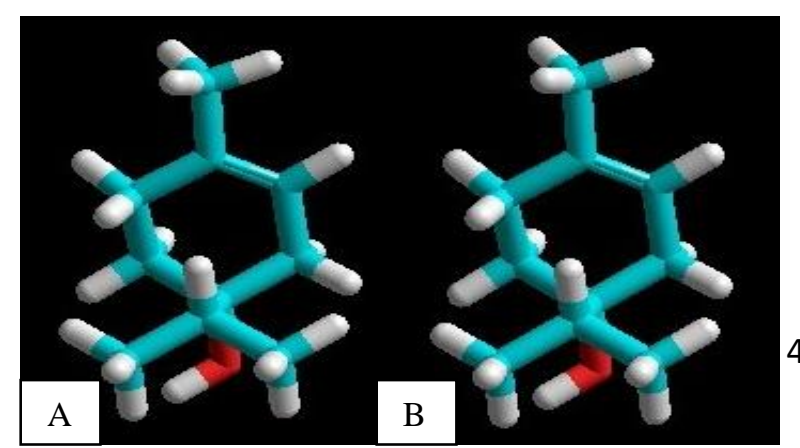

Gambar 3. Struktur 3D Terpinen-4-ol dengan kalkulasi single point (A) dan Optimasi

Geometri (B)

Tabel 2. Hasil Docking Terpinen-4-ol

\begin{tabular}{|l|c|l|l|}
\hline Ligan & $\begin{array}{c}\text { Energi } \\
\text { Ikatan } \\
(\mathrm{kkal} / \mathrm{mo} \\
\mathrm{l})\end{array}$ & $\begin{array}{c}\text { Residu } \\
\text { Asam } \\
\text { Amino }\end{array}$ & Gugus \\
\hline $\begin{array}{c}\text { Terpine } \\
\text { n-4-ol }\end{array}$ & $-4,89$ & Leu83 & HN-O \\
\cline { 2 - 4 } & Leu83 & O-H \\
\hline
\end{tabular}

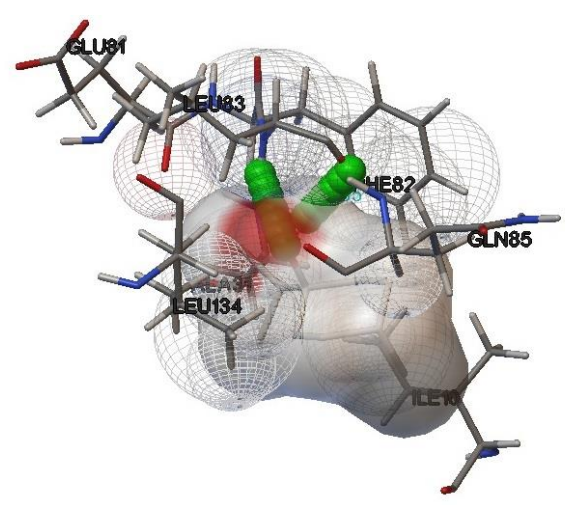

Gambar 4. Visualisasi Interaksi Terpinen-4-ol dengan Protein IKK

dengan protein saat dilakukan redocking. Sedangkan ikatan hidrogen adalah salah satu ikatan non kovalen yang mempunyai peran penting dalam penentuan aktivitas biologi yang dihasilkan (Wijaya dkk., 2003).

Struktur 3D terpinen-4-ol digambar kemudian dilakukan pengukuran single point untuk mengetahui energi awal dari struktur. Energi yang diperoleh saat dilakukan kalkulasi single point terpinen 4-ol sebesar -2892,702163 $\mathrm{kkal} / \mathrm{mol}$, kemudian dilakukan optimasi geometri. Pada proses optimasi geometri, 
energi akan diminimalisasi sehingga terjadi penurunan energi dan diperoleh struktur senyawa yang lebih stabil (Fitriasari dkk., 2008). Energi struktur terpinen-4-ol setelah dilakukan optimasi geometri yaitu $-2907,5570$ $\mathrm{kkal} / \mathrm{mol}$.

Hasil yang diperoleh dari proses docking antara terpinen-4-ol dengan protein IKK berupa energi ikatan dan ikatan hidrogen pada sepuluh konformasi terbaik. Semakin kecil energi ikatan yang diperoleh maka semakin stabil ikatan yang terjadi antara terpinen-4-ol dengan protein tersebut. Energi ikatan terpinen-4-ol dengan protein IKK yaitu $-4,89$ $\mathrm{kkal} / \mathrm{mol}$. Energi ikatan tersebut lebih besar dibandingkan dengan native ligand-nya. Hal ini menunjukkan bahwa afinitas terpinen-4-ol lebih rendah pada protein tersebut,namun masih dapat membentuk ikatan hidrogen dengan sisi aktif dari protein-protein target serta energi ikatan yang dihasilkan bernilai negatif. Selain diperoleh energi ikatan, proses docking juga menghasilkan data ikatan hidrogen antara terpinen-4-ol dengan protein target, dimana terbentuk 2 ikatan hidrogen yang melibatkan residu Leu83.

Berdasarkan hasil yang diperoleh terpinen-4-ol berpotensi mampu mencegah pembentukan plak aterosklerosis melalui jalur inflamasi dengan menghambat protein-protein

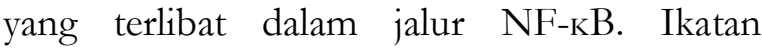
terpinen-4-ol dengan protein tersebut dapat menghambat transkripsi gen proinflamasi dan migrasi otot polos sehingga pembentukan plak dapat dihambat.

\section{KESIMPULAN}

Terpinen-4-ol berpotensi menghambat pembentukan plak pada aterosklerosis karena memiliki afinitas terhadap protein IKK melalui pembentukan ikatan hidrogen dengan protein

Koontongkaew, S., Meesuk, L., Aupaphong, V., Dechatiwongse Na Ayudhya, T. and Poachanukoon, O. 2013. Inhibitory Effect of Zingiber cassumunar Extract tersebut sehingga dapat mencegah inflamasi dalam pembentukan plak secara in silico.

\section{UCAPAN TERIMAKASIH}

Penulis mengucapkan terimakasih kepada semua pihak yang telah membantu penelitian ini.

\section{DAFTAR PUSTAKA}

Bissantz, C., Folkers, G., and Rognan, D. 2000. Protein-Based Virtual Screening of Chemical Databases. 1. Evaluation of Dofferent Docking/Scoring Combinations. Journal of Medicinal Chemistry. Vol.43:4759-4767.

Douglas, G., Channon, K.M. 2014. The Pathogenesis of Atherosclerosis. Medicine.Vol.42:480-484.

Fitriasari, A., Wijayanti, N. K., Ismiyati, N., Dewi, D., Kundarto, W., Sudarmanto, B. S. A., dan Meiyanto., E. 2008. Studi Potensi Kurkumin dan Analognya sebagai Selective Estrogen Receptor Modulator (SERMs): Docking pada Reseptor Estrogen B. Pharmacon.Vol.9:27-32.

Francis, A. A. and Pierce, G.N. 2011. An Integrated Approach dor The Mecanism Responsible for Atherosclerotic Plaque Regression. Experimental and Clinical Cardiology.Vol.16:77-86.

Hadi, A. R. H., Carr, C.S. and Suwaidi, J.A. 2005. Endothelial Dysfungtion: Cardiovascular Risk Factors, Therapy, and Outcome. Vascular Health and Risk Management.Vol. 1:183-198.

Jain, A. N. and A. Nicholls. 2008. Recommendation for Evaluation of Computational Methods. Journal of Computer-Aided Molecular Design. Vol.22:133-139.

on Lipopolysaccharide-Induced Cyclooxygenase-2 and Matrix Metalloproteinase Expression in Human Gingival Fibroblasts. J Periodont.Vol.48:507-516. 
Susanti dkk.

DOI: https://doi.org/10.24843/JFU.2019.v08.i01.p07

pISSN: 2301-7716; eISSN: 2622-4607

Jurnal Farmasi Udayana, Vol 8, No 1, Tahun 2019, 44-49

Montalescot, G., Sechtem, U., Achenbach, S., Andreotti, F., Arden, C., Budaj, A., et al. 2013. 2013 ESC Guidelines in The Management of Stable Coronary Artery Disease. European Heart Journal.Vol.34:2949-3003.

Nauli, T. 2014. Penentuan Sisi Aktif Selulase Aspergillus Niger dengan Docking Ligan, JKTI.Vol. 16: 94-100.

Tedgui, A. and Mallat, Z. 2006. Cytokines in Atherosclerosis: Pathogenic and Regulatory Pathways.Physicological Reviews.Vol. 86:515-581.

Warboys, C. M., Amini, N., Luca, A.D. and Evans, P.C. 2011. The Role of Blood Flow in Determining The Sites of

Atherosclerotic Plaque. F1000 Report Medicine.Vol. 3:1-8.

Wijaya, K., Tahir, I., dan Harnowo. 2003. Study of Double Protons Migration Mechanism in Supramolecular Structures of Acetic Acid-Water and Acetic Acid Ammonia by $A b$ Initio Method, Indonesian Journal of Chemistry.Vol. 3:102-110.

World Health Organization. 2017, Cardiovascular Disesase (CVDs), Available at http://www.who.int/en/newsroom/fact-sheets/detail/cardiovasculardiseases-(cvds) [Cited on October 2018]. 